\title{
Effects of Ascorbic Acid Injection in Incubated Eggs Submitted to Heat Stress on Incubation Parameters and Chick Quality
}

http://dx.doi.org/10.1590/1516-635x1702181-190

\section{-Author(s)}

Sgavioli S

Matos Júnior JB"

Borges LL"

Praes MFFM'

Morita VS"

Zanirato GL"

Garcia RG'

Boleli IC"

Universidade Federal de Grande Dourados, Dourados, MS.

" Universidade Estadual Paulista Júlio de Mesquita Filho, Jaboticabal, SP.

\section{Mail Address}

Corresponding author e-mail address Sarah Sgaviol

Rua Oliveira Marques, 3730 bloco H ap 34 79830-902, Dourados, MS, Brazil

E-mail: sarahsgavioli@yahoo.com.br

\section{nKeywords}

Conductance, hatchability, egg mass loss, hatchling weight, eggshell temperature.

\section{ABSTRACT}

Dose-dependent positive effects on hatchability and hatchling weight have been attributed to ascorbic acid (AA) when eggs were submitted or not to intermittent heat stress during incubation. Fertile breeder $(\mathrm{Cobb} \otimes)$ eggs were used to determine if the pre-incubation injection of $A A$ in ovo affects the incubation and hatchling quality of egg incubated under thermoneutral or intermittent heat stress conditions. Eggs were not injected or injected with $0,2,4$, or $6 \%$ AA $100 \mu \mathrm{L}$ water and incubated at continuous thermoneutral $\left(37.5^{\circ} \mathrm{C}\right)$ or hot $\left(39.0^{\circ} \mathrm{C}\right)$ temperature. Eggshell temperature (EST) increased in the second half of the incubation period in all experimental groups. The EST of non-injected eggs and of those injected with water was higher when incubated at $39^{\circ} \mathrm{C}$ than at $37.5^{\circ} \mathrm{C}$, but EST was not different among eggs injected with AA. Egg mass loss and eggshell conductance were higher in the eggs incubated at $39^{\circ} \mathrm{C}$ than at $37.5^{\circ} \mathrm{C}$. Hatchability was lower in the eggs injected with AA. Liver and yolk sac weights were higher, whereas heart and liver weights were lower in hatchlings from eggs incubated at $39^{\circ} \mathrm{C}$; however, hatchling weight was not affected by incubation temperature. The results showed that AA doses affected egg conductive heat loss and hatchability, and that they did not minimize the effects of high incubation temperature on liver and heart development.

\section{INTRODUCTION}

During in-ovo development, the chicken embryo does not control its body temperature (Wekstein \& Zolman, 1967, 1969; Freeman, 1971), making it highly dependent from the air temperature inside the incubator. The onset and maintenance of embryo development requires the eggs to absorb heat from the incubator air. On the other hand, during the second half of the incubation period, the eggs need to loose heat to the environment of the incubator, as embryo metabolic rate and heat production increase (French, 1997).Although the function of the eggshell is to separate the internal egg contents from the external environment, it does not provide complete thermal isolation, allowing heat exchange between the egg and the incubator, which are required for the ontogenetic development in ovo. Therefore, the embryo is vulnerable to temperatures above or below optimal incubation temperature.

From the physiological and production perspectives, incubation management practices should aim at maximizing hatchling quality, as good quality chicks have higher chances to express the full genetic potential of their genetic line. Incubation temperatures above that considered optimal for domestic poultry $\left(37-38^{\circ} \mathrm{C}\right.$; Romanoff, 1960; French, 1997) negatively affect hatchability and reduce both hatchling quality (Hagger et al., 1986; French, 2000; Leksrisompong et al., 2007; 
Sgavioli S, Matos Júnior JB, Borges LL, Praes MFFM, Morita VS, Zanirato GL, Garcia RG, Boleli IC
Effects of Ascorbic Acid Injection in Incubated Eggs Submitted to Heat Stress on Incubation Parameters and Chick Quality
Willemsen et al., 2011; Boleli \& Queiroz, 2012) and growth performance after hatch (Decuypere et al., 1979; Geers et al., 1982).

The in-ovo injection of nutrients may be used to improve hatchability and hatchling quality (Ohta et al., 2001).For instance, the injection of vitamins in ovo has been applied to improve hatchability and hatchling body weight (Robel \& Christensen, 1991; Robel, 1993). Ascorbic acid (AA, vitamin C) has shown dosedependent positive effects on hatchability and hatchling body weight (Zakaria \& Al-anezi, 1996; Pires et al., 2011; Ghonim et al., 2009; Mohammed et al., 2011; Nowaczewski et al., 2012) when eggs are incubated or not under intermittent heat stress. However, the effects of the injection of AA pre-incubation of eggs incubated under continuous heat stress on embryo development and hatchling quality are not known. Therefore, the present study evaluated if the intra-ovo injection of AA before incubation affected incubation quality (eggshell temperature and conductance, eggmass loss, hatchability, and embryo mortality) and hatchling quality (body weight and organ weights, and body surface temperature) of eggs incubated under continuous heat stress conditions or not.

\section{MATERIAL AND METHODS}

The experimental protocol was approved by the Animal Ethics Committee (CEUA) of the School of Agrarian and Veterinary Sciences of Universidade Estadual Paulista (UNESP), Jaboticabal campus, Brazil, under protocol n. 7377/10.

Five hundred fertile eggs derived from 47-weekold Cobb® broiler breeders were acquired from a commercial hatchery (Globoaves, Itirapina, SP, Brazil). Eggs were individually weighed and allotted to a completely randomized experimental design in a $5 \times 2$ factorial arrangement, with five ascorbic acid treatments (no injection or injection with $0,2,4$, or $6 \%$ ascorbic acid per $100 \mu$ l of water intra-ovo) and two incubation temperatures (thermoneutral: $37.0,{ }^{\circ} \mathrm{C}$ or hot: $39.0^{\circ} \mathrm{C}$ ), with two incubators per temperature, each with 50 eggs per treatment. Average egg weight was $67 \pm 2 \mathrm{~g}$. The incubators (Premium Ecológica, IP200) had automatic temperature control and egg turning every $2 \mathrm{~h}$. Relative humidity was maintained at $60 \%$ until eggs were transferred to the hatcher and at $70 \%$ during the last two days of incubation.

Ascorbic-acid injection was performed before eggs were incubated. After cleaning the egg surface with $100 \%$ ethanol, the eggshell was perforated with a sterile needle (Injex, $13 \times 0.38(27.5$ G1/2")), and the AA solution (Synth, 99\% purity) was injected in the albumen at an approximate depth of $6 \mathrm{~mm}$ from the eggshell. Eggs were placed horizontally, and the solution was applied in the end of the egg opposite to the air chamber. After injection, the hole was closed with a label identifying treatment and replicate. The AA solution was diluted in Mili-Q water and autoclaved in a dark environment due its photosensitivity.

The following parameters were evaluated: eggshell temperature, egg mass loss, eggshell conductance, hatchling body temperature, hatchability, embryo mortality, duration of incubation, hatchling relative weight and absolute and relative weights of the liver, yolk sac, heart, and gizzard.

\section{Eggshell temperature}

Eggshell temperature was measured in two eggs/ AA treatment/temperature/incubator, totaling 20 eggs. Values were recorded during the entire incubation period using $T$ mini-thermocouples (copper-constant; Alutal).The thermocouples were attached to the side of the eggs using an adhesive tape, covering a circular surface of $1 \mathrm{~cm}$ diameter. Eggs were placed on the incubator pulleys with the longitudinal axis placed horizontally. Data were collected and stored every 30 minutes from d1 to 18 of incubation. Data were stored in data loggers and downloaded in a computer for subsequent analysis. Eggshell temperature was analyzed for first 18 incubation days.

\section{Egg mass loss and eggshell conductance}

Egg mass loss was calculated as the difference in egg weight before placement and an on d 18 of incubation, and expressed as a percentage of initial egg weight. Eggshell conductance was calculated as egg mass loss ( $\mathrm{g}$ ) from placement divided by steam saturation pressure $\left(23.86 \mathrm{~mm} / \mathrm{Hg}\right.$ at $\left.25^{\circ} \mathrm{C}\right)$.

\section{Hatchling body temperature and quality}

Wing, head, shank, and back temperatures of male chicks were recoded using an infrared thermometer and average body surface temperature ( $T$ ) was calculated as: average surface temperature $=(0.12 \mathrm{x}$ wing $\mathrm{T})+(0.03 \mathrm{x}$ head $\mathrm{T})+(0.15 \mathrm{x}$ shank $\mathrm{T})+(0.70 \mathrm{x}$ back T), as described by Richard (1971).

Absolute and relative weights of the fresh liver, yolk sac, heart, and gizzard were determined at hatch in eight male chicks/treatment after sacrifice by neck dislocation followed by head section. Organ relative weights were calculated as a function of hatchling body weight. 


\section{Hatchability, embryo mortality, and duration of incubation}

Hatchability (number of hatched chicks/number of incubated eggs), embryo mortality according to embryodiagnosis phases (initial: 1-7 days; intermediate: 8-14 days; and late: 15-21 days of incubation), and duration of incubation (number of hours from placement to hatch) were determined.

Hatchling absolute body weight (g) was measured after the down dried, and hatchling body weight relative to egg weight (g) was calculated and expressed in \%.

\section{Statistical analysis}

The obtained data were submitted to analysis of variance using the General Linear Model (GLM) procedure of SAS statistical package (SAS Institute, 2002). When significant effects were determined (7\% probability), means were compared by the test of Tukey. Linear, quadratic, and cubic models were used for regression analyses to evaluate the effects of ascorbic acid levels.

\section{RESULTS}

\section{Eggshell temperature (EST)}

Figure 1 shows the EST of eggs injected or not with $A A$ and incubated at thermoneutral $\left(37.5^{\circ} \mathrm{C}\right)$ or hot $\left(39^{\circ} \mathrm{C}\right)$ temperature, as estimated by thermocouples kept in direct contact with the eggshell. When incubated at $37.5^{\circ} \mathrm{C}$, the EST of non-injected eggs (controls) exceeded the incubation temperature from d 10 , reaching a maximum value of approximately $38.2^{\circ} \mathrm{C}$ on $\mathrm{d} 17$ and 18 . The EST of eggs injected with water exceeded the incubation temperature only on $\mathrm{d} 17$ and in about $0.2^{\circ} \mathrm{C}$. The EST of the eggs injected with $A A$ remained higher than the incubation temperature $\left(37^{\circ} \mathrm{C}\right)$ during the entire incubation, being $0.5^{\circ} \mathrm{C}$ and $1.1^{\circ} \mathrm{C}$ higher, on average, on day 10 and 17 , respectively. When incubated at $39^{\circ} \mathrm{C}$, the EST of the non-injected eggs (control) remained lower than the incubation temperature until d 14, whereas those injected with water (0\% $A A)$ reached incubation temperature only on d 18. The EST of the eggs injected with 4 and $6 \%$ AA remained below incubation temperature during the entire incubation and reached incubation temperature only on d 18, whereas the EST of those injected with $2 \%$ AA exceeded incubation temperature on $\mathrm{d} 13$, and remained about $0.2^{\circ} \mathrm{C}$ higher until d 18.

EST values were also compared between incubation periods (d 1-9 and d 10-18) and was significantly higher $(p<0.05)$ during the second period (Figure2).

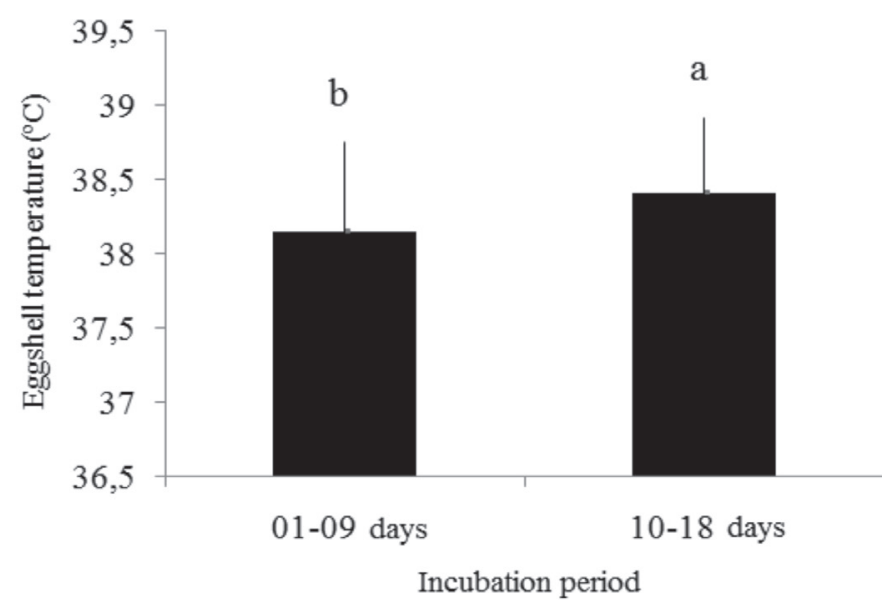

Figure 2 - Eggshell temperature during the incubation temperatures of 01-09 and 10-18 days. a-b:means followed by different letters are significantly different $(p<0.05)$.

As shown in Table 1, there was a significant interaction $(p<0.05)$ both between incubation temperature and days of incubation and incubation 
Table 1 - Effects of the in-ovo injection of ascorbic acid, incubation temperature, and incubation days on eggshell temperature.

\begin{tabular}{ll}
\hline Sources of variation & Probability for analysis of variance \\
\hline Incubation temperature $(T)$ & $<0.0001^{* *}$ \\
\hline Days of incubation (D) & $<0.0001^{* *}$ \\
\hline AA dose (AA) & $<0.0001^{* *}$ \\
\hline$T \times D$ & $<0.0001^{* *}$ \\
\hline$A A \times T$ & $<0.0001^{* *}$ \\
\hline AA x D & $0.6716^{\mathrm{NS}}$ \\
\hline Coefficient of variation $(\%)$ & $0.52^{\mathrm{NS}}$ \\
\hline$* *(p \leq 0.05) .{ }^{\text {Ns }}$ not significant. &
\end{tabular}

temperature and AA doses for EST. During the incubation period, EST increased $(p<0.05)$ in eggs incubated at both temperatures and was higher $(p<0.05)$ in those incubated at $39^{\circ} \mathrm{C}$ than at $37.5^{\circ} \mathrm{C}$ (Table 2). In addition, Table 3 shows that the EST of non-injected eggs (controls) and of those injected with water $(0 \%$ AA) was higher when eggs were incubated at $39^{\circ} \mathrm{C}$ than at $37.5^{\circ} \mathrm{C}$, whereas the EST of $A A$-injected eggs was not influenced by incubation temperature $(p<0.05)$. There was no influence of the AA treatment when eggs were incubated at $39^{\circ} \mathrm{C}$

Table 2 - Deployment of the interaction between incubation temperature and days of incubation for eggshell temperature.

\begin{tabular}{|c|c|c|c|c|}
\hline \multirow{2}{*}{\multicolumn{2}{|c|}{$\begin{array}{l}\text { Days } \\
\text { incubation }\end{array}$}} & \multicolumn{2}{|c|}{ Incubation temperature } & \multirow[t]{2}{*}{$P$} \\
\hline & & Thermoneutral & Hot & \\
\hline 1 & & $37.50 \mathrm{~b}$ & $38.09 a$ & $<0.0001 * *$ \\
\hline 2 & & $37.54 b$ & $38.63 a$ & $<0.0001$ ** \\
\hline 3 & & $37.50 b$ & $38.32 a$ & $<0.0001 * *$ \\
\hline 4 & & $37.54 b$ & $38.37 a$ & $<0.0001 * *$ \\
\hline 5 & & $37.56 b$ & $38.40 a$ & $<0.0001 * *$ \\
\hline 6 & & $37.56 b$ & $38.45 a$ & $<0.0001 * *$ \\
\hline 7 & & $37.54 b$ & $38.49 a$ & $<0.0001$ ** \\
\hline 8 & & $37.56 \mathrm{~b}$ & $38.53 a$ & $<0.0001 * *$ \\
\hline 9 & & $37.67 b$ & $38.53 a$ & $<0.0001 * *$ \\
\hline 10 & & $37.77 b$ & $38.50 a$ & $<0.0001$ ** \\
\hline 11 & & $37.79 b$ & $38.58 a$ & $<0.0001 * *$ \\
\hline 12 & & $37.85 b$ & $38.62 a$ & $<0.0001 * *$ \\
\hline 13 & & $37.92 b$ & $38.60 a$ & $<0.0001 * *$ \\
\hline 14 & & $38.02 b$ & $38.77 a$ & $<0.0001 * *$ \\
\hline 15 & & $38.16 b$ & $38.88 a$ & $<0.0001 * *$ \\
\hline 16 & & $38.26 \mathrm{~b}$ & $38.92 a$ & $<0.0001 * *$ \\
\hline 17 & & $38.32 b$ & $38.94 a$ & $<0.0001 * *$ \\
\hline 18 & & $38.36 b$ & $38.16 a$ & $<0.0001$ ** \\
\hline
\end{tabular}

Table 3 - Deployment of the interaction between in-ovo injection of ascorbic acid and incubation temperature for eggshell temperature.

\begin{tabular}{|c|c|c|c|}
\hline \multirow{2}{*}{ Treatments } & \multicolumn{2}{|c|}{ Incubation temperature } & \multirow[t]{2}{*}{$P$} \\
\hline & Thermoneutral & Hot & \\
\hline Control & $37.56 \mathrm{bB}$ & $38.70 a$ & $0.0221 * *$ \\
\hline $\begin{array}{l}\text { Ascorbic acid at } \\
0 \%\end{array}$ & $36.96 \mathrm{bB}$ & $38.66 a$ & $0.0023 * *$ \\
\hline $\begin{array}{l}\text { Ascorbic acid at } \\
2 \%\end{array}$ & $38.05 \mathrm{~A}$ & 38.70 & $0.1537^{N S}$ \\
\hline $\begin{array}{l}\text { Ascorbic acid at } \\
4 \%\end{array}$ & $38.25 \mathrm{~A}$ & 38.71 & $0.3017^{\text {NS }}$ \\
\hline $\begin{array}{l}\text { Ascorbic acid at } \\
6 \%\end{array}$ & $38.07 \mathrm{~A}$ & 38.30 & $0.5941^{\text {NS }}$ \\
\hline$P$ & $0.0644^{*}$ & $0.8288^{N S}$ & \\
\hline
\end{tabular}

( $p>0.05$ ), but when incubated at $37.5^{\circ} \mathrm{C}$, eggs injected with $\mathrm{AA}(2 \%, 4 \%$, and $6 \%)$ presented higher EST than the control and the water-injected eggs $(p<0.07)$.

\section{Egg mass loss, eggshell conductance, and hatchling body temperature}

The results on Table 4 show that AA doses did not influence $(p>0.05)$ egg mass loss or eggshell conductance; however, these parameters were significantly $(p<0.05)$ affected by incubation

Table 4 - Effects of the in-ovo injection of ascorbic acid and incubation temperature on egg mass loss, eggshell conductance, and hatchling body surface temperature.

\begin{tabular}{|c|c|c|c|}
\hline & $\begin{array}{c}\text { Egg mass loss } \\
(\%)\end{array}$ & Conductance & $\begin{array}{l}\mathrm{BST}^{1} \\
\left({ }^{\circ} \mathrm{C}\right)\end{array}$ \\
\hline \multicolumn{4}{|l|}{ AA dose (AA) } \\
\hline Control & 8.86 & 0.371 & 31.21 \\
\hline Ascorbic acid at $0 \%$ & 9.11 & 0.382 & 30.69 \\
\hline Ascorbic acid at $2 \%$ & 8.80 & 0.369 & 30.74 \\
\hline Ascorbic acid at $4 \%$ & 9.08 & 0.380 & 30.92 \\
\hline Ascorbic acid at $6 \%$ & 9.63 & 0.404 & 30.79 \\
\hline \multicolumn{4}{|l|}{$\begin{array}{l}\text { Incubation } \\
\text { temperature }(T)\end{array}$} \\
\hline Thermoneutral & $8.59 b$ & $0.360 \mathrm{~b}$ & 30.89 \\
\hline Hot & $9.61 a$ & $0.403 a$ & 30.86 \\
\hline \multicolumn{4}{|l|}{ Probability } \\
\hline AA & $0.0977^{\mathrm{NS}}$ & $0.0982^{\text {NS }}$ & $0.5075^{\mathrm{NS}}$ \\
\hline$T$ & $<0.0001 * *$ & $<0.0001 * *$ & $0.5198^{\mathrm{NS}}$ \\
\hline$A A \times T$ & 0.5271 Ns & $0.5227^{\mathrm{NS}}$ & $0.0660 *$ \\
\hline $\begin{array}{l}\text { Coefficient of } \\
\text { variation (\%) }\end{array}$ & 15.79 & 15.80 & 3.52 \\
\hline
\end{tabular}

${ }^{*} p \leq 0.07 .{ }^{* *}(p \leq 0.05) . a-b, A-B:$ Means followed by different letters in the same column are significantly different. ${ }^{\text {NS }}$ not significant. ${ }^{1}$ body surface temperature 
Sgavioli S, Matos Júnior JB, Borges LL, Praes MFFM, Morita VS, Zanirato GL, Garcia RG, Boleli IC

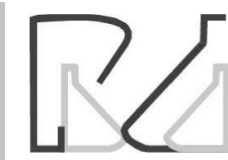

temperature, with higher values obtained in the eggs incubated at $39^{\circ} \mathrm{C}$ than at $37.5^{\circ} \mathrm{C}$. There was a significant interaction $(p<0.07)$ between AA treatment and incubation temperature for average hatchling surface temperature (Table 4): the body temperature of chicks hatched from eggs injected with water $(0 \%$ AA) was lower when eggs were incubated at hot temperature $(p<0.05$; Table 5$)$.

Table 5 - Deployment of the interaction between in-ovo injection of ascorbic acid and incubation temperature for hatchling body surface temperature.

\begin{tabular}{lccc}
\hline \multirow{2}{*}{ Treatments } & \multicolumn{2}{c}{ Incubation temperature } & \multirow{2}{*}{$P$} \\
\cline { 2 - 3 } & Thermoneutral & Hot & \\
\hline Control & 30.93 & 31.46 & $0.2659^{\mathrm{NS}}$ \\
\hline Ascorbic acid at 0\% & $31.31 \mathrm{a}$ & $30.15 \mathrm{~b}$ & $0.0415^{* *}$ \\
\hline Ascorbic acid at 2\% & 30.68 & 30.78 & $0.8309^{\mathrm{NS}}$ \\
\hline Ascorbic acid at 4\% & 31.47 & 30.68 & $0.1804^{\mathrm{NS}}$ \\
\hline Ascorbic acid at 6\% & 30.44 & 31.03 & $0.1889^{\mathrm{NS}}$ \\
\hline P & $0.3449^{\mathrm{NS}}$ & $0.1206^{\mathrm{NS}}$ & \\
\hline Linear effect of AA levels & $0.3005^{\mathrm{NS}}$ & $0.0926^{\mathrm{NS}}$ & \\
\hline $\begin{array}{l}\text { Quadratic effect of AA } \\
\text { levels }\end{array}$ & $0.6303^{\mathrm{NS}}$ & $0.6631^{\mathrm{NS}}$ & \\
\hline Cubic effect of AA levels & $0.0992^{\mathrm{NS}}$ & $0.3990^{\mathrm{NS}}$ & \\
\hline
\end{tabular}

** $(p \leq 0.05)$. a-b:Means followed by different letters in the same column are significantly different. N5not significant.
Effects of Ascorbic Acid Injection in Incubated Eggs Submitted to Heat Stress on Incubation Parameters and Chick Quality

\section{Hatchability, embryo mortality, and dura- tion of incubation}

Data on Table 6 showed significant effects $(p<0.05)$ of the AA treatment on hatchability, which was higher for the non-injected eggs (controls) compared with those injected, with the lowest hatchability recorded in eggs injected with 4\% AA. Early (d 0-7), intermediate (d 8-14), and late (d 15-hatch) embryo mortality were not influenced by AA treatment or by incubation temperature. However, embryo mortality was numerically higher in all phases in injected than in non-injected eggs. The injection of $4 \%$ AA increased early embryo mortality in $80 \%$, intermediate embryo mortality in $65 \%$ and late embryo mortality in $115 \%$ relative to the control eggs, which seems to correspond to the lower hatchability recorded in chicks derived from eggs injected with 4\% AA. Moreover, early embryo mortality was higher when eggs were incubated at the hot temperature.

Incubation period was negatively influenced ( $>0.05$ ) by incubation temperature (Table 5), being longer when eggs were incubated at $39^{\circ} \mathrm{C}$ than at $37.5^{\circ} \mathrm{C}$

\section{Hatchling quality}

Table 7 shows the obtained hatchling quality parameters. Hatchling relative weight was not influenced ( $p>0.05$ ) by AA dosing or by incubation temperatures. The absolute and relative weights of

Table 6 - Effects of in-ovo ascorbic acid injection and incubation temperature on hatchability, embryo mortality, and duration of incubation.

\begin{tabular}{|c|c|c|c|c|c|}
\hline & \multirow{2}{*}{$\begin{array}{c}\text { Hatchability } \\
(\%)\end{array}$} & \multicolumn{3}{|c|}{ Embryo mortality (\%) } & \multirow{2}{*}{$\begin{array}{c}\mathrm{DI}^{1} \\
\text { (hours) }\end{array}$} \\
\hline & & $0-7$ days & 7-14 days & 14-21 days & \\
\hline \multicolumn{6}{|l|}{ AA dose (AA) } \\
\hline Control & $86.72 a$ & 21.67 & 0.00 & 78.33 & 490.17 \\
\hline Ascorbic acid at $0 \%$ & $75.80 \mathrm{~b}$ & 31.77 & 22.86 & 45.47 & 491.91 \\
\hline Ascorbic acid at $2 \%$ & $70.40 \mathrm{bc}$ & 21.50 & 20.00 & 45.17 & 492.66 \\
\hline Ascorbic acid at $4 \%$ & $63.20 c$ & 38.89 & 14.44 & 46.67 & 493.47 \\
\hline Ascorbic acid at $6 \%$ & $74.40 b$ & 23.24 & 9.05 & 63.71 & 490.52 \\
\hline \multicolumn{6}{|l|}{ Incubation temperature $(\mathrm{T})$} \\
\hline Thermoneutral & 75.70 & 15.95 & 18.69 & 58.69 & $506.06 \mathrm{a}$ \\
\hline Hot & 73.04 & 35.02 & 9.66 & 53.99 & $478.49 \mathrm{~b}$ \\
\hline \multicolumn{6}{|l|}{ Probability } \\
\hline AA & $0.0028^{* *}$ & $0.7553^{\mathrm{NS}}$ & 0.3859 NS & 0.2387 Ns & $0.4566^{\text {NS }}$ \\
\hline $\mathrm{T}$ & $0.3583^{\mathrm{NS}}$ & $0.1248^{\mathrm{NS}}$ & $0.3176^{\mathrm{NS}}$ & $0.7056^{\mathrm{NS}}$ & $<0.0001$ ** \\
\hline $\mathrm{AA} \times \mathrm{T}$ & $0.5617^{\mathrm{NS}}$ & $0.7234^{\mathrm{NS}}$ & $0.2863^{\mathrm{NS}}$ & $0.2817^{\mathrm{NS}}$ & $0.4477^{\text {NS }}$ \\
\hline Coefficient of variation (\%) & 9.27 & 104.85 & 161.33 & 53.49 & 2.23 \\
\hline
\end{tabular}

${ }^{* *}(p \leq 0.05)$. a-b:Means followed by different letters in the same column are significantly different. ${ }^{N 5}$ not significant. ${ }^{1}$ duration of incubation. 
Table 07 - Effects of in-ovo ascorbic acid injection and incubation temperature on male hatchling quality.

\begin{tabular}{|c|c|c|c|c|c|c|c|c|c|}
\hline & BW & Liver $^{1}$ & Yolk sac & Heart & Gizzard & Liver $^{1}$ & Yolk sac & Heart & Gizzard \\
\hline & (\%) & \multicolumn{4}{|c|}{ (g) } & \multicolumn{4}{|c|}{$(\%)$} \\
\hline \multicolumn{10}{|l|}{ AA dose (AA) } \\
\hline Control & 74.51 & $0.98(0.90)$ & 8.96 & 0.31 & 1.96 & $1.87(2.34)$ & 17.05 & 0.60 & 3.75 \\
\hline Ascorbic acid at $0 \%$ & 73.97 & $1.14(0.96)$ & 9.10 & 0.34 & 1.66 & $2.17(2.35)$ & 17.16 & 0.64 & 3.12 \\
\hline Ascorbic acid at $2 \%$ & 74.55 & $1.02(0.92)$ & 9.68 & 0.34 & 1.68 & $2.08(2.41)$ & 18.18 & 0.65 & 3.16 \\
\hline Ascorbic acid at $4 \%$ & 74.34 & $1.26(1.00)$ & 9.34 & 0.31 & 1.51 & $2.46(2.37)$ & 18.04 & 0.61 & 2.90 \\
\hline Ascorbic acid at $6 \%$ & 74.64 & $1.16(0.97)$ & 9.51 & 0.34 & 1.71 & $2.33(2.39)$ & 17.83 & 0.64 & 3.21 \\
\hline \multicolumn{10}{|l|}{$\begin{array}{l}\text { Incubation } \\
\text { temperature (T) }\end{array}$} \\
\hline Thermoneutral & 74.42 & $0.98(0.90) b$ & $8.69 b$ & $0.37 a$ & $1.86 a$ & $1.99(2.31) b$ & $16.44 b$ & $0.70 a$ & $3.53 a$ \\
\hline Hot & 74.39 & $1.25(1.00) \mathrm{a}$ & $9.89 a$ & $0.30 \mathrm{~b}$ & $1.53 b$ & $2.39(2.43) \mathrm{a}$ & $18.78 a$ & $0.56 b$ & $2.90 \mathrm{~b}$ \\
\hline \multicolumn{10}{|l|}{ Probability } \\
\hline AA & $0.4179^{\mathrm{NS}}$ & $0.4564^{\mathrm{NS}}$ & $0.5933^{\mathrm{NS}}$ & $0.2427^{\mathrm{NS}}$ & $0.3227^{\mathrm{NS}}$ & $0.5369^{\mathrm{NS}}$ & $0.6345^{\text {NS }}$ & $0.4253^{\text {NS }}$ & $0.2877^{\mathrm{NS}}$ \\
\hline $\mathrm{T}$ & $0.8021^{\text {NS }}$ & $0.0143^{* *}$ & $0.0002^{* *}$ & $<0.0001^{* *}$ & $0.0128^{* *}$ & $0.0002^{* *}$ & $<0.0001 * *$ & $<0.0001 * *$ & 0.0121 ** \\
\hline $\mathrm{AA} \times \mathrm{T}$ & $0.2115^{\mathrm{NS}}$ & 0.7361 Ns & $0.5055^{\text {NS }}$ & $0.6217^{\text {NS }}$ & 0.6467 Ns & $0.5754^{\text {NS }}$ & $0.5831^{\text {NS }}$ & $0.5466^{\text {NS }}$ & $0.7112^{\mathrm{NS}}$ \\
\hline CV (\%) & 2.88 & 16.31 & 14.50 & 16.42 & 30.92 & 5.25 & 13.52 & 15.66 & 30.65 \\
\hline
\end{tabular}

$\mathrm{CV}=$ coefficient of variationBW:body weight. ${ }^{* *}$ : $\mathrm{p} \leq 0.05$. a-b:Means followed by different letters in the same column are significantly different ( $\left.\mathrm{p} \leq 0.05\right) .{ }^{1}:$ comparison based on log-transformed data (between parenthesis). ${ }^{\mathrm{N}}$ not significant.

the liver, yolk sac, heart, and gizzard were significantly affected $(p<0.05)$ by incubation temperature, but not by AA treatment. The absolute and relative weights of the yolk sac and the liver were higher and those of the heart and the gizzard were lower when eggs were incubated at $39^{\circ} \mathrm{C}$ compared with $37.5^{\circ} \mathrm{C}$

\section{DISCUSSION}

Eggshell surface temperature is used as an indication of metabolic heat production intra ovo (Lourens et al., 2007). In the present study, EST was higher in eggs incubated at $39^{\circ} \mathrm{C}$ than at $37.5^{\circ} \mathrm{C}$ during the entire incubation period, indicating that hot incubation temperature increases embryo and fetus metabolism. EST increases during the second half of incubation as embryo metabolic rate and heat production increase (Meijerhof, 1999; Tazawa \& Whittow, 2000). The obtained data showed that EST increased in the second half of incubation both at the applied thermoneutral and hot temperatures, independently of AA dose injected in ovo, demonstrating that the increase in embryo metabolic rate was not prevented by incubation temperature or by AA injection.

Heat is transferred by conduction, convection and evaporation when there are temperature differences within an environment or between different environments (La Scala, 2003), which means that heat exchange between egg content and incubator air during incubation can only occur if and when their respective temperatures are different. Heat loss by conduction corresponds to the propagation of heat from the egg content to the surface of the eggshell, which then transfers heat to the air by convection and by radiation (La Scala, 2003), allowing eggshell temperature to be used as an indication of egg heat loss. On the other hand, heat loss by evaporation corresponds to the heat lost along with egg mass (water) loss, and it is proportional to egg mass (La Scala, 2003). According to French (1997), eggs absorb heat from the incubator during the first half of the incubation period - provided the embryo temperature is lower than that of the incubator -, but must loose heat during the second half, when their metabolic rate and heat production increase. In the present study, when incubated at the thermoneutral temperature $\left(37.5^{\circ} \mathrm{C}\right)$, only the noninjected eggs and those injected with water gained heat during the first half and lost heat during the second half of incubation. However, conductive heat loss may have been lower in the latter as their EST was higher than the incubation temperature after $\mathrm{d} 10$ and 17 of incubation, respectively. The EST of the AA-injected eggs remained higher than incubation temperature during the entire incubation period, indicating higher conductive heat loss compared with the non-injected and water-injected eggs. This may explain the lower hatchability of AA-injected eggs, which did not lose heat for the incubator air during the second half of incubation. 
Differently from the eggs incubated at thermoneutral temperature, the EST of non-injected and waterinjected eggs was higher when eggs were incubated at $39^{\circ} \mathrm{C}$ than at $37.5^{\circ} \mathrm{C}$, probably because they did not lose heat by conduction under hot temperature incubation.

Conductance is the capacity of gas exchange between the egg and the environment, and it is related with water (Campos et al., 2003) and metabolic heat (Hamidu et al., 2007) losses. The higher the egg conductance and the water loss, the higher egg heat loss by evaporation. The results showed that, compared with eggs incubated at $37.5^{\circ} \mathrm{C}$, those incubated at $39^{\circ} \mathrm{C}$ presented higher egg mass loss and conductance, but no differences in hatchability. This indicates that the increase in evaporative heat loss of the eggs incubated at the hot temperature may have prevented the negative effects of the lack of conductive heat loss (EST data) on embryo development and the consequent reduction of their hatchability. The higher mass loss observed in the eggs incubated at $39^{\circ} \mathrm{C}$ may have resulted from increased water evaporation of the egg contents and higher metabolic water production (Shafey, 2002).

Excessive egg water loss (>14\%) causes embryo death by dehydration (Romanoff, 1930); on the other hand, egg mass loss between 11 and $12 \%$ up to 18 days of incubation increases hatchability (Rosa et al., 1999). In the present study, egg mass loss of the eggs incubated at $39^{\circ} \mathrm{C}$ was approximately $9.6 \%$, and therefore, was lower than $14 \%$ and very close to the values of 10.8 and $10 \%$ recorded by Deeming (1996) and Rosa et al. (1996), respectively, in eggs incubated at $37.8^{\circ} \mathrm{C}$ and therefore, did not affect hatchability.

The in-ovo injection of AA did not influence egg evaporative heat loss, but hatchability was significantly reduced, particularly when eggs were injected with 4\% AA. According to Uni \& Ferket (2003), solutions at high concentrations may affect egg osmotic balance, and consequently embryo development. Those authors recommend a maximum limit of 800 mOsm. However, the osmolarity of the in-ovo AA solution injected (113 mOsm) was below that limit, suggesting that the lower hatchability of the AA-injected eggs was not caused by osmotic balance changes. Our data do not agree with the findings of Pires et al. (2011), who obtained higher hatchability when eggs were injected with $1 \%$ AA. The dose-dependent effect of AA on hatchability was also recorded by Zakaria \& Al-Anezi (1996), Elibol et al. (2001), Ipek et al. (2004), and Nowaczewski et al. (2012), who obtained better results when eggs were injected with 3 and 6 mg of AA. However, those authors injected this vitamin at later stages of incubation, indicating that its effects on in-ovo development varies with its dose and stage of embryo development at the time of injection.

Lower hatchability and higher incidence of embryo abnormalities have been reported in eggs submitted to long (French, 1994) or short periods of hyperthermia (French, 2000). In the current experiment, despite the higher egg mass loss and the shorter incubation period of eggs incubated at $39^{\circ} \mathrm{C}$, hatchability was similar between the eggs incubated at the two different temperatures, indicating that the hot incubation temperature did not limit in-ovo development, as previously observed by Gualhanone (2002) in eggs incubated at $38.8^{\circ} \mathrm{C}$.

Shorter incubation times are associated with faster mitosis and higher metabolic rate of somatic cells, accelerating embryo growth (Kojima et al., 1996). Our results show that the duration of incubation was shortened when eggs were incubated at $39^{\circ} \mathrm{C}$ compared with $37.5^{\circ} \mathrm{C}$, indicating that the hot incubation temperature accelerated in-ovo development, as confirmed by their higher conductive and evaporative heat losses and higher conductance, and therefore, higher metabolic rate. On the other hand, AA injection did not affect the ontogenetic development of chicks, in agreement with the findings of El-Sheikh \& ElGammal (2000) and Mohammed et al. (2011), who did not find any effects of AA administration in ovo on the duration of incubation.

Egg mass loss up at the time of transference to the hatcher is used in commercial settings to determine embryo development stage and it is related with hatchling weight (Noy \& Pinchasov, 1993). However, despite the higher egg mass loss of the eggs incubated at $39^{\circ} \mathrm{C}$ than at $37.5^{\circ} \mathrm{C}$, hatchling weight was not different. This may have been due to the action of regulation mechanisms that limit the influence of the environment during the incubation on egg parameters, such as egg mass loss (Simkiss, 1980 a, b), making the embryos tolerate different egg water loss rates during incubation by changing the amount of water absorbed from the allantoic fluid. The egg weight to hatchling weight ratios (hatchling relative weight) obtained in the present study are within the $73-80 \%$ interval considered normal for chickens by Henry \& Burke (1997). On the other hand, hatchling derived from eggs incubated at $39^{\circ} \mathrm{C}$ presented higher liver weight and lower gizzard and heart weight compared with those incubated at the thermoneutral temperature. 
According to Lilja \& Olsson (1987), the ontogenetic development of broilers selected for rapid growth after hatching is characterized by the preferential growth of supply organs (heart, liver, and gut). Therefore, the greater liver development seems to be and adaptive response related with the increased embryo metabolism rate induced by the hot incubation temperature. Interestingly, despite the greater metabolic rate of the embryos incubated at $39^{\circ} \mathrm{C}$ in the present study, the hatchling presented heart hypoplasia, suggesting that supply organs were not equally influenced by the hot incubation temperature. It must be mentioned that heart hypoplasia may cause cardiac deficit and compromise chick development, resulting in the emergence of ascites during the grow-out period. Moreover, embryos derived from eggs incubated at the high temperature presented lower utilization of the yolk sac, as previously observed by Molenaar et al. (2011), who obtained heavier yolk sacs in hatchlings from eggs incubated at $38.9^{\circ} \mathrm{C}$. This indicates lower chick quality and results in higher mortality during the first week due to yolk sac infections.

\section{CONCLUSIONS}

The in-ovo injection of ascorbic acid in Cobb eggs before incubation did not minimize the effects of high incubation temperature $\left(39^{\circ} \mathrm{C}\right)$, which negatively affected their hatchability.

\section{ACKNOWLEDGEMENTS}

This research project was funded by Fundação de Amparo à Pesquisa do Estado de São Paulo (Fapesp). Processes n.2010/15280-0 and 2010/01923-7.

\section{REFERENCES}

Campos EJ, Santos JEC. O efeito de linhagens sobre o desenvolvimento embrionário. In: Macari M, Gonzales E, editors. Manejo da Incubação. Campinas: Facta; 2003. p.97-124.

Decuypere E,Nouwen EJ,Kühn ER,Geers R, Michels H. Differences in serum iodohormone concentration between chick embryos with and without the bill in the air chamber at different incubation temperatures. General Comparative Endocrinology1979;37:264-267

Deeming DC. Turning helps hatchability. Poultry Misset 1996;4(4): 27

Elibol O, Türkoglu M, Akan M, Erol H. Inkubasyon sırasında agirr yumurtalara askorbik asit enjeksiyonunun kuluçka özelliklerine etkisi. Turkish Journal oh Veterinary and Animal Sciences 2001;25:245-248.

El-Sheikh TM, El-Gammal AM. Effect of the holding temperature, holding period as well as vitamin C supplementation on hatching traits of Dandarawi eggs. Egypt Poultry Science Journal 2000;20:839- 855.
Freeman BM. Body temperature and thermoregulation. In: Bell DJ, Freeman BM, editors. Physiology and biochemistry of the domestic fowl. London: Academic Press; 1971. p.1115-1151.

French NA. Effect of incubation temperature on the gross pathology of turkey embryos. British Poultry Science 1994;35:363-371.

French NA. Effect of short periods of high incubation temperature on hatchability and incidence of embryo pathology of turkey eggs. British Poultry Science2000;41:377-382.

French NA. Modeling incubator temperature: The effects of incubator design, embryonic development, and egg size. Poultry Science1997;76:124-133

Geers R, Michels H, Tanghe P.Growth, maintenance requirements and feed efficiency of chickens in relation to prenatal environmental temperatures. Growth 1982;46:26-35.

Ghonim AIA, Awad AL, Fattouh MHA, El-Shhat AM. Comparative study of ascorbic acid treatment methods on hatchability traits and growth performance of ducklings. EgyptPoultry Science 2009;29:1085-1099.

Gualhanone A. Estudo da variação da temperatura da superfície da casca de ovos provenientes de matrizes de 30 e 60 semanas de idade durante a incubação [dissertação]. Jaboticabal (SP): UniversidadeEstadualPaulista; 2002

Hagger C, Steiger-Staff D, Marguerat C. Embryonic mortality in chicken eggs as influenced by egg weight and inbreeding. Poultry Science $1986 ; 65: 812-814$.

Hamidu JA,Fasenko GM,Feddes JJR,O'dea EE, Ouellette CA, Wineland MJ, et al. The effect of broiler breeder genetic strain and parent flock age on eggshell conductance and embryonic metabolism. Poultry Science 2007; 86:2420-2432

Henry MH, Burke WH. Sexual Dimorphism in broiler chick embryos and embryonic muscle development in late incubation. Poultry Science $1997 ; 77: 728-36$.

Hoyt PF. Osmoregulation by avian embryos: the allantois functions like a toad's bladder. Physiological Zoology 1979;25:354-362.

Ipek A, Sahan U, Ylmaz B. The effect of in ovoascorbic acid and glucose injection in broiler breeder eggs on hatchability and chick weight. Archives Geflügelk 2004;68:132-135.

Kojima T, Udagawa K, Onishi A, Iwahashi H, Komatsu Y. Effect of heat stress on development in vitro and in vivo and on synthesis of heat shock proteins in porcine embryos. Molecular Reproduction Development 1996; 43:452-557.

La Scala JR. Aspectos físicos da incubação. In: Macari M, Gonzales E editores.Manejo da incubação. Campinas: Facta; 2003. p.97-124.

Leksrisompong N, Romero-Sanchez H, Plumstead PW, Brannan KE, Brake J. Broilerincubation. 1. Effect of elevated temperature during late incubation on body weight and organs of chicks. Poultry Science 2007;86:2685-2691

Lilja C, Olsson N. Changes in embryonic development associated with long-term selection for high growth rate in Japanese quail. Growth 1987:51:301-308.

Lourens A, Brand van den $\mathrm{H}$, Heetkamp MJW, Meijerhof R, Kemp B. Effects of eggshell temperature and oxygen concentration on embryo growth and metabolism during incubation. Poultry Science 2007:86:21942199.

MeijerhofR. Embryo temperature is the key factor in incubation. World Poultry - Elsevier 1999;15:42-43 
Mohammed KA, El-Boghdady A,SolimanMAH,Abd Al-GalilMA,Abd AlAleem NM.The effect of both pre-incubation dipping eggs in vitamin $\mathrm{C}$ and cooling eggs during incubation period on embryonic and hatchability parameters in two local chicken strains. Egypt Poultry Science 2011;31(2):379-392.

Molenaar R, Anker van den I, Meijerhof R, Kemp B, Brand van den H. Effect of eggshell temperature and oxygen concentration during incubation on the developmental and physiological status of broiler hatchlings in the perinatal period. Poultry Science 2011; 90:1257-1266.

Nowaczewski S, Kontecka H, Krystianiak S. Effect of in ovo injection of vitamin $C$ during incubation on hatchability of chickens and ducks. Folia Biologica 2012;60:93-97.

Noy Y,Pinchasov Y. Effect of a single pos hatch incubation of nutrients on subsequent early performance of broiler chicks and turkey poults. Poultry Science 1993;72:1861-1866.

Ohta Y,Kidd MT, Ishibashi T. Embryo growth and amino acid concentration profiles of broiler breeder eggs, embryos, and chicks after in ovoadministration of amino acids.Poultry Science 2001;80:1430-1436.

Pires DL, Sgavioli Sarah, Malheiros EB,BolelilC .Acido ascórbico in ovo sobre a eclodibidade de ovos. Anais da $21^{\text {a }}$ Reunión de la Asociación Latinoamericana de Producción Animal - ALPA; 2011; Montevideo. Uruguai.

Richards SA. The significance of changes in the temperature of the skin and body core of the chicken in the regulation of heat loss. Journal of Physiology 1971;216:1-10

Robel EJ, Christensen VL.Increasing hatchability of turkey eggs by injecting eggs with pyridoxine. British Poultry Science 1991;32:509-513.

Robel EJ. Evaluation of egg injection method of pantothenic acid in turkey eggs and effect of supplemental pantothenic acid on hatchability. Poultry Science 1993;72:1740-1745.

Romanoff AL. Biochemistry and biophysics of the development hen's egg. Memoirs of Cornell University Agricultural Experimental Station 1930;132:1-27

Romanoff AL. The extra embryonic membranes in the avian embryo, structural and 18 functional development. New York: MacMillan Company; 1960.
Rosa PS, Scheuermann GN, Figueiredo EAP. Influência da umidade na incubadora sobre o desempenho de incubação em ovos com diferentes densidades específicas. Anais da Conferência Apinco de Ciência e Tecnologia Avícolas; 1999; Campinas, São Paulo. Brasil. p.10.

Rosa PS, Guidoni AL, Lima IL. Influência da temperatura de incubação em ovos de matrizes de corte com diferentes idades e classificados por peso sobre os resultados de incubação. Revista Brasileira de Zootecnia 2002;31(2):1011-1016

SAS Institute. SAS proprietary software. Release 9.2. Cary, NC; 2002.

Shafey TM. Egg shell conductance, embryonic growth, hatchability and embryonic mortality of broiler breeder eggs dipped into ascorbic acid solution. British Poultry Science 2002;43:135-140.

Simkiss K. Eggshell porosity and the water metabolism of the chick embryo. Journal of Zoology 1980a;12:1-8.

Simkiss K. Water and ionic fluxes inside the egg. American Zoologist 1980b;20:385-393.

Tazawa H, Whittow GC. Incubation physiology. In: Sturkey's avian physiology. London: Academic Press; 2002. p.617-634.

Uni Z, Ferket RP. Enhancement of oviparous species by in ovo feeding. US Patent 6.592.878 B2. Raleigh: North Carolina State University; 2003.

Wekstein DR, Zolman IF.Homeothermic development of the young chick. Proceedings of the Society for Experimental Biology and Medicine 1967;125:294-297.

Wekstein DR, Zolman JF. Ontogeny of heat production in chicks. Federation of American Societies for Experimental Biology 1969; 28:1023-1028.

Willemsen $\mathrm{H}$, Li, Willems Y, Franssens E, Wang Y, Decuypere E. Intermittent thermal manipulations of broiler embryos during late incubation and their immediate effect on the embryonic development and hatching process. Poultry Science 2011;90:1302-1312.

Zakaria $\mathrm{AH}$, Al-Anezi MA, Effect of ascorbic acid and cooling during egg incubation on hatchability, culling, mortality and the body weights of broiler chickens. Poultry Science 1996;75:1204-1209. 
